\title{
Pengaruh Pemberian Ekstrak Kencur (Kaempferia galanga L.) terhadap Peningkatan Zona Hambat Pertumbuhan Bakteri Staphylococcus aureus
}

\author{
Linda Putri Utami*, Peter Gunawan Tandean, Liliawanti \\ Fakultas Kedokteran, Universitas Hang Tuah Surabaya \\ *e-mail: lindaputriutami2@gmail.com
}

\begin{abstract}
Abstrak
Prevalensi penyakit infeksi di Indonesia masih tergolong tinggi, diantaranya adalah disebabkan oleh Staphylococcus aureus. Indonesia memiliki banyak tanaman tradisional yang dapat di gunakan dalam pengobatan herbal karena mengandung tanin, flavonoid, dan minyak atsiri. Selain itu, juga karena memiliki aktivitas sebagai antibakteri yang relatif tinggi karena dapat membentuk zona penghambatan pada bakteri Staphylococcus aureus. S. Aureus dapat menyebabkan infeksi kulit, keracunan makanan hingga infeksi sistemik. Oleh karena itu kencur dapat digunakan sebagai obat alternatif. Penelitian ini bertujuan untuk mengetahui adanya pengaruh pemberian ekstrak kencur (Kaempferia galanga L.) dalam menghambat pertumbuhan bakteri Staphylococcus aureus. Penelitian ini bersifat eksperimental laboratorium yang menggunakan metode difusi lempeng rancangan "Postest Ony Control Group Design". Terdapat 7 kelompok, 5 kelompok perlakuan dan 2 kelompok kontrol. Konsentrasi kelompok perlakuan ialah 100\%, 50\%, 25\%, 12,5\%, 6,25\% sedangkan untuk kontrol positif menggunakan amoxicillin $25 \mu \mathrm{g}$ dan Aquadest sebagai kontrol negatif. Bakteri yang digunakan adalah Staphylococcus aureus. Ekstrak kencur (Kaempferia galanga L.) mempunyai pengaruh antibakteri dalam menghambat pertumbuhan bakteri Staphylococcus aureus. Dengan nilai $p=0,001$ atau $p<\alpha$. Ekstrak kencur (Kaempferia galanga L.) mempunyai pengaruh antibakteri dalam menghambat pertumbuhan bakteri Staphylococcus aureus.
\end{abstract}

Kata Kunci: Staphylococcus aureus, kencur, antibakteri

\section{The Effect of Kencur Extract (Kaempferia Galanga L.) Against Increase Blockade Zone of Staphylococcus aureus Bacterial Growth}

\begin{abstract}
The prevalence of infectious diseases in Indonesia is still relatively high, for example Infection caused by Staphylococcus aureus. Indonesia has many traditional plants that can be used for herbal treatments containing tannins, flavonoids, and essential oils which have relatively high antibacterial activity by forming inhibitory zones in the Staphylococcus aureus bacteria which are the cause of skin infections food poisoning to systemic infections. Thereforekencur can be used as an alternative medicine. This study was intented to determine the effect of giving kencur extract (Kaempferia galanga L.) In inhibiting the growth of Staphylococcus aureus bacteria. This study was experimental laboratory used plate diffusion method of "Postest Ony Control Group Design" design. There were 7 groups, 5 treatment groups and 2 control groups. The concentration of treatment group was 100\%, 50\%, 25\%, 12,5\%, 6,25\% while for positive control using amoxicillin $25 \mu \mathrm{g}$ and aquadest as negative control. The bacterial used were Staphylococcus aureus. The results showed that kencur extract (Kaempferia galanga L.) had an antibacterial effect in inhibiting the growth of Staphylococcus aureus bacteria. With a value of $p$
\end{abstract}


Pengaruh Pemberian Ekstrak Kencur (Kaempferia galanga L.) terhadap Peningkatan Zona...

Linda Putri Utami, Peter Gunawan Tandean, Liliawanti

$=0.001$ or $p<\alpha$. kencur extract (Kaempferia galanga L.) has an antibacterial effect in inhibiting the growth of Staphylococcus aureus bacteria.

Keywords: Staphylococcus aureus, kencur, antibacterial.

\section{PENDAHULUAN}

Staphylococcus aureus merupakan bakteri komensalisme dan patogen pada manusia. Sekitar $30 \%$ dari populasi manusia dikolonisasi oleh Staphylococcus aureus, bakteri ini menjadi suatu masalah ketika terdapat suatu fokus infeksi dan dapat menyebar dari satu orang ke orang lain melalui kontak langsung atau melalui objek yang terkontaminasi (Sari, 2017).

Staphylococcus aureus merupakan bakteri gram positif berbentuk bulat berdiameter 0,7-1,2 $\mu \mathrm{m}$, tersusun dalam kelompok-kelompok yang tidak teratur seperti buah anggur, fakultatif anaerob, tidak membentuk spora, dan tidak bergerak. Berdasarkan bakteri yang tidak membentuk spora, maka Staphylococcus aureus termasuk jenis bakteri yang paling kuat daya tahannya. Pada agar miring dapat tetap hidup sampai berbulan-bulan, baik dalam lemari es maupun pada suhu kamar (MuhAnshar, 2017). Biakan Staphylococcus aureus tumbuh dengan baik pada berbagai media bakteriologi di bawah suasana aerobik dan mikroaerobik. Tumbuh dengan cepat pada temperatur $37^{\circ} \mathrm{C}$. Pembentukan pigmen yang terbaik adalah pada temperatur kamar $\left(20-35^{\circ} \mathrm{C}\right)$.
$\mathrm{pH}$ optimal untuk pertumbuhan yaitu 7,4. Media untuk pertumbuhan Staphylococcus aureus umumnya mengandung asam amino dan vitamin-vitamin seperti thereonin, asam nikotinat, dan biotin (Elisa, 2010).

Staphylococcus aureus merupakan salah satu bakteri patogen penting yang berkaitan dengan virulensi toksik, invasif, dan ketahanan terhadap antibiotik (Rahmi et al, 2015), hampir tiap orang akan mengalami beberapa tipe infeksi Staphylococcus aureus sepanjang hidupnya. Setiap jaringan ataupun alat tubuh dapat terinfeksi dan menyebabkan timbulnya penyakit dengan tanda-tanda khas yanitu peradangan nekrosis dan pembentukan abses. Infeksinya dapat berupa furunkel yang ringan pada kulit sampai berupa suatu piemia yang fatal. Umumnya bakteri ini menimbulkan penyakit yang bersifat sporadik (Inayatullah, 2012). Pada manusia, Staphylococcus aureus dapat menimbulkan berbagai macam penyakit, diantaranya bisul borok, impetigo, pneumonia, osteomielistis, meningitis, mastitis, bakteremia, keracunan makanan, infeksi urogenital dan sindrom syok toksik 
(Haerazi et al, 2014). Studi epidemiologi menunjukkan bahwa infeksi akibat Staphylococcus aureus di dunia meningkat pada dua dekade terakhir. Data di Amerika Serikat dan Eropa menunjukkan bahwa Staphylococcus aureus merupakan bakteri patogen tersering penyebab infeksi dengan prevalensi $18-30 \%$, sedangkan diwilayah Asia Staphylococcus aureus dan Pseudomonas aeruginosa memiliki angka kejadian infeksi yang hampir sama banyak (Sari, 2017).

Indonesia dengan keaneka ragaman hayati t7rkenal dengan sumber daya alamnya yang melimpah, salah satunya yaitu memiliki aneka ragam tumbuhan yang digunakan sebagai obat tradisional. Salah satu tanaman yang paling banyak digunakan di masyarakat adalah kencur. Kencur merupakan tanaman obat yang bernilai ekonomis cukup tinggi sehingga banyak dibudayakan (Muhafidzah, 2010). Kencur mempunyai kandungan kimia antara lain minyak atsiri $2,4-2,9 \%$ yang terjadi atas etil parametoksi sinamat (30\%), kamfer, borneol, sineol, penta dekana. Adanya kandungan etil para meloksi sinamat dalam kencur yang merupakan senyawa turunan sinamat (Prabawati Tuti, 2018). Produksi, mutu, dan kandungan bahan aktif di dalam rimpang Kencur ditentukan oleh varietas, cara budidaya, dan lingkungan tempat tumbuhnya. Jadi dapat dikatakan bahwa, kandungan Kencur di daerah yang berbeda memilki kemungkinan kandungan senyawa kimia yang berbeda (Primawati \& Jannah, 2019).

Kencur (Kaempferia galanga L.) banyak digunakan sebagai bahan baku obat tradisional (jamu), fitofarmaka, industri kosmetika, penyedap makanan dan minuman, rempah, serta bahan campuran saus, rokok pada industri rokok kretek. Secara empirik kencur digunakan sebagai penambah nafsu makan, infeksi bakteri, obat batuk, disentri, tonikum, ekspektoran, masuk angin, sakit perut (Kumar, 2014). Selain itu kencur (Kaempferia galanga L.) mempunyai aktivitas antiinflamasi yang diiuji pada radang akut (Hasanah, 2011) Berdasarkan penjelasan diatas, peneliti mencoba untuk mengetahui pengaruh ekstrak kencur (Kaempferia galanga L.) terhadap zona hambat pertumbuhan bakteri Staphylococcus aureus. Pada penelitian ini digunakan ekstrak kencur (Kaempferia galanga L.) dengan penambahan pelarut seperti ethanol untuk mendapatkan senyawa aktif dari kencur. Pada penerapannya, hal ini diharapkan dapat sebagai antibiotik alami sehingga masyarakat dapat lebih mudah membuatnya.

Tujuan penelitian ini untuk mengetahui daya hambat pemberian 
Pengaruh Pemberian Ekstrak Kencur (Kaempferia galanga L.) terhadap Peningkatan Zona... Linda Putri Utami, Peter Gunawan Tandean, Liliawanti

ekstrak kencur (Kaempferia galanga L.) terhadap Staphylococcus aureus dan mengidentifikasikan besar konsentrasi ekstrak kencur (Kaempferia galanga L.) yang dapat menghambat bakteri Staphylococcus aureus.

\section{BAHAN DAN METODE}

Rancangan penelitian yang
digunakan adalah post test only control
group design untuk mengetahui
kemampuan ekstrak kencur (Kaempferia
galangat.) terhadap pertumbuhan
Staphylococcus aureus. Eksperimen ini
menggunakan teknik difusi untuk
mengetahui kepekaan bakteri. Sampel
yang digunakan dalam penelitian ini adalah
Staphylococcus aureus yang diperoleh dari
hasil pemeriksaan biakan laboratorium
yang diidentifikasi secara standart di
Laboratorium Mikrobiologi Fakultas
Kedokteran Universitas Hang Tuah
Surabaya.

\section{Persiapan Peralatan}

Alat-alat yang digunakan dalam penelitian ini rak, tabung reaksi, cawan petri, tabung erlenmeyer, ose steril, mikropipet, inkubator, cakram kertas steril, lidi kapas steril, autoclave, timbangan analitik, pinset steril, vortex, kertas saring, blender, pipet, rotary evaporator, api busen, dan digital calipers.

\section{Persiapan Bahan}

Bahan-bahan yang digunakan dalam penelitian ini adalah ekstrak kencur (Kaempferia galanga L.), koloni bakteri Staphylococcus aureus, mueller hinton agar plate, mueller hinton broth, aquadest steril, cakram antibiotik amoxicillin, paper disk, dan larutan standar MC farland 0,5.

\section{Pembuatan Ekstrak}

Kencur dicuci sampai bersih lalu dikeringkan kemudian kencur yang sudah kering diblender hingga berbentuk bubuk lalu ditimbang beratnya. Bubuk kencur sebanyak $350 \mathrm{gr}$ kemudian direndam dalam larutan etanol 96\% didiamkan dalam suhu ruangan selama $3 \times 24$ jam kemudian pengadukan dilakukan setiap hari. Campuran organik kemudian difiltrasi menggunakan vaccum filter setiap $1 \times 24$ jam. Filtrat dipisahkan dari pelarut dengan menggunakan rotary evaporator pada suhu kurang dari $50^{\circ} \mathrm{C}$ dan menghasilkan ekstrak kencur

\section{Persiapan Suspense Bakteri}

Uji bakteri Staphylococcus aureus diambil dari biakan murni media agar Mueller Hinton yang disesuaikan kekeruhannya dengan standar 0,5 McFarland.

\section{Persiapan Media Mueller Hinton Agar}

Sebanyak 38 gram (Mueller Hinton Agar) dilarutkan dalam masing-masing 1 liter aquadest kemudian dididihkan. Larutan media kemudian disterilisasi dalam 
autoclave pada suhu $121^{\circ} \mathrm{C}$ selama 15 menit, Kemudian menunggu suhu sampai hangat $\left(45^{\circ} \mathrm{C}-50^{\circ} \mathrm{C}\right)$ lalu menuangkan kedalam cawan petri steril dan disimpan pada suhu $2-8^{\circ} \mathrm{C}$.

\section{Pembuatan Larutan Uji}

Pembuatan larutan uji, dengan menyediakan 5 buah tabung reaksi yang masing-masing dari tabung diberi keterangan $100 \%, 50 \%, 25 \%, 12,5 \%$, dan 6,25\%. Larutan uji 100\% didapatkan dari 1 ml ekstrak kencur kemudian dihomogenkan dengan alat vortex. Larutan uji $50 \%$ didapat dari mengambil sebanyak $1 \mathrm{ml}$ larutan uji $100 \%$ kemudian ditambahkan aquades steril sebanyak $1 \mathrm{ml}$ lalu dihomogenkan dengan menggunakan alat vortex. Larutan uji $25 \%$ didapat dari mengambil sebanyak $1 \mathrm{ml}$ larutan uji 50\% kemudian ditambahkan aquades steril sebanyak $1 \mathrm{ml}$ lalu dihomogenkan dengan menggunakan alat vortex. Larutan uji $12,5 \%$ didapat dari mengambil sebanyak $1 \mathrm{ml}$ larutan uji 25\% kemudian ditambahkan aquades steril sebanyak $1 \mathrm{ml}$ lalu dihomogenkan dengan menggunakan alat vortex dan Larutan uji 6,25\% didapat dari mengambil sebanyak $1 \mathrm{ml}$ larutan uji $12,5 \%$ kemudian ditambahkan aquades steril sebanyak $1 \mathrm{ml}$ lalu dihomogenkan dengan menggunakan alat vortex.
Uji Kepekaan Bakteri Dengan Cara Difusi Menggunakan Lempeng Agar Mueller Hinton

Mengambil bakteri dari agar Mueller Hinton kemudian ditanamkan pada media cair Mueller Hinton lalu diinkubasi pada suhu $34-37^{\circ} \mathrm{C}$ selama $18-24$ jam. Menyamakan kekeruhan bakteri sesuai dengan standart Mc Farland 0,5, kemudian lidi kapas steril dicelupkan pada suspense kuman kemudian sedikit ditekan pada bagian dalam tabung (diperas) sehingga tidak terlalu basah. Mengusapkan lidi kapas pada permukaan agar Mueller Hinton lalu dibiakan kering pada suhu ruangan. Kertas cakram yang telah dicelupkan ke masing-masing konsentrasi larutan uji. Meletakkan kertas cakram yang telah dicelupkan selama 5 detik dengan menggunakan pinset steril diatas media agar dengan sedikit ditekan. Kontrol positif menggunakan antibiotik amoxicillin $25 \mu \mathrm{g}$, sedangkan kontrol negatif menggunakan aquadest steril lalu diinkubasi pada suhu $37^{\circ} \mathrm{C}$ selama 24 jam. Dilakukan pengamatan dan dicatat pertumbuhan bakteri pada setiap cawan petri. Mengukur zona hambat menggunakan digital calipers dalam milimeter dan hasil pengukuran zona hambat yang diperoleh merupakan rata-rata pengukuran dari 3 arah ukur diameter zona hambat. 
Pengaruh Pemberian Ekstrak Kencur (Kaempferia galanga L.) terhadap Peningkatan Zona... Linda Putri Utami, Peter Gunawan Tandean, Liliawanti

\section{Analisi Data}

Analisis data hasil penelitian menggunakan uji statistic one-way ANNOVA. Penggunaan uji ini dilakukan jika data berdistribusi normal dan varians data homogen. Apabila salah satu syarat tidak terpenuhi maka dilakukan uji satistik Kruskal Wallis. Kruskal wallis adalah uji non parametrik yang digunakan untuk membandingkan tiga atau lebih kelompok data sampel dan skala pengukuran ordinal.

\section{HASIL}

Hasil penelitian yang dilakukan yaitu uji aktivitas antibakteri ekstrak kencur
(Kaempferia galanga L.) di Laboratorium Mikrobiologi Fakultas Kedokteran Universitas Hang Tuah Surabaya dengan variasi konsentrasi $100 \%, 50 \%, 25 \%, 12,5 \%$, 6,25\% pada Staphylococcus aureus dengan metode difusi. Metode ini menggunakan media Mueller Hinton Agar. Antibiotik Amoxicilin digunakan sebagai kontrol positif dan pemberian Aquades sebagai kontrol negatif pada Staphylococcus aureus. Kemudian dilakukan inkubasi selama 24 jam dan pengukuran zona hambat atau Daerah Hambat Pertumbuhan dengan hasil seperti yang tercantum pada Gambar 1.

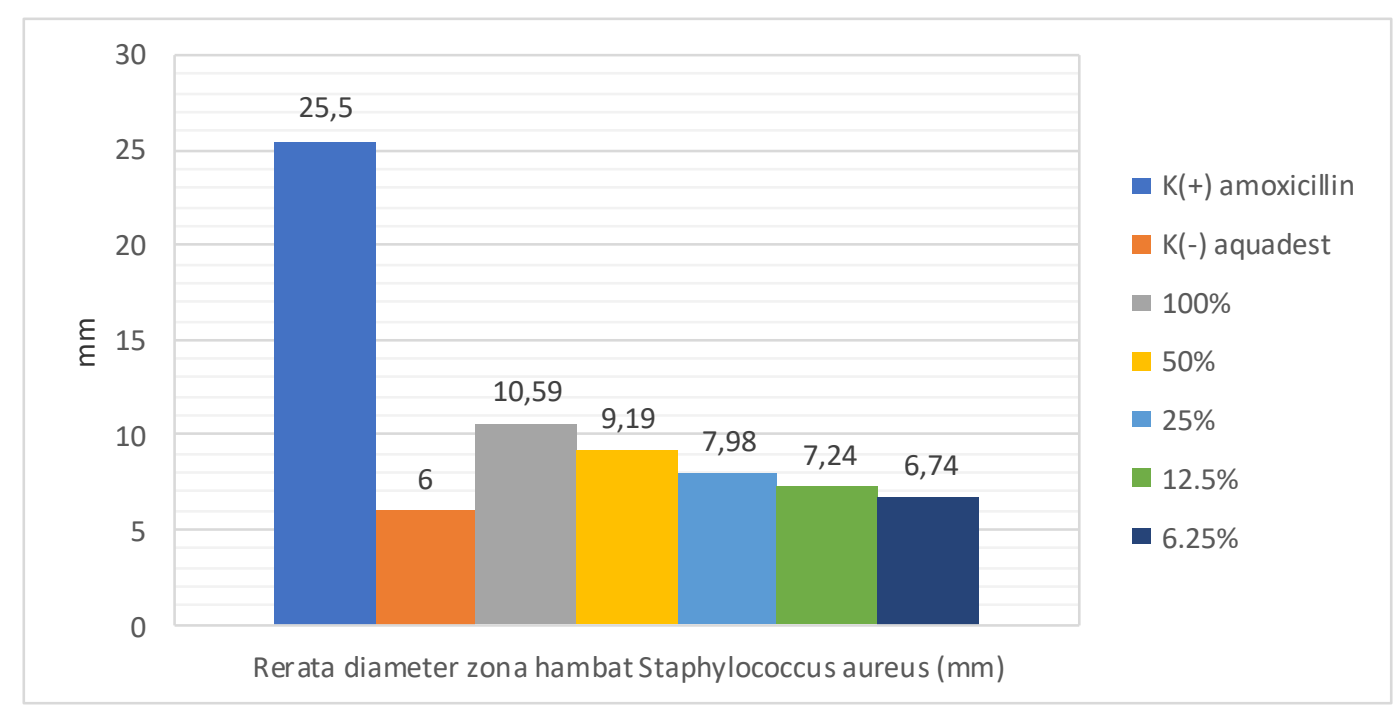

Gambar 1. Grafik Rerata diameter zona hambat ekstrak Kencur terhadap Staphylococcus aureus

Berdasarkan Gambar 1, pemberian

Ekstrak Kencur memberikan pengaruh pada pertumbuhan bakteri Staphylococcus aureus, hal ini dibuktikan dengan terbentuknya zona hambat pada pertumbuhan bakteri. Hasil yang didapatkan berbeda dan bermakna antara Amoxicilin sebagai kontrol positif, aquades sebagai kontrol negatif dan ekstrak kencur dengan berbagai variasi kadar konsentrasi, $100 \%, 50 \%, 25 \%, 12,5 \%$, dan $6,25 \%$ terhadap Staphylococcus aureus. 
Konsentrasi Ekstrak Kencur 100\% memiliki daya hambat terhadap pertumbuhan bakteri Staphylococcus aureus lebih besar dibandingkan dengan konsentrasi yang lainnya tetapi tidak lebih besar daripada kontrol positifnya, yaitu Amoxicilin. Dari konsentrasi 50\%, 25\%, $12,5 \%$, dan $6,25 \%$ dapat dilihat bahwa zona hambatnya lebih besar dibandingkan dengan aquadest sebagai kontrol negatif. Berdasarkan hasil uji statistic didapatkan hasil perbandingan kelompok Amoxicilin dengan kelompok aquades, ekstrak kencur dengan konsentrasi $100 \%, 50 \%, 25 \%$, $12,5 \%$, dan $6,25 \%$ memiliki perbedaan yang signifikan dengan maksud memang ada perbedaan yang signifikan dari konsentrasi ekstrak Kencur yang terkecil hingga yang paling besar, walaupun demikian dari konsentrasi 100\% ekstrak Kencur masih belum mampu lebih baik efektifitasnya dibandingkan dengan Amoxicilin.

$$
\text { Pada kelompok aquades }
$$
dibandingkan dengan kelompok ekstrak kencur dengan konsentrasi 100\%, 50\%, $25 \%, 12,5 \%$, dan $6,25 \%$ memiliki perbedaan berarti sehingga pada kadar tersebut efektifitasnya tidak sama dengan aquades. Konsentrasi 100\%, 50\%, 25\%, $12,5 \%$, dan $6,25 \%$ lebih efektif daripada aquades karena adanya kandungan kimia dalam ekstrak kencur yang mampu menghambat pertumbuhan bakteri seperti senyawa tanin, flavonoid dan minyak atsiri. Pada kelompok ekstrak kencur dengan konsentrasi $100 \%$ dibandingkan dengan konsentrasi 50\% tidak memiliki perbedaan yang signifikan sehingga pada kadar tersebut memiliki efektifitas yang hampir sama dengan kadar ekstrak kencur konsentrasi $100 \%$. Tetapi ekstrak kencur konsentrasi $100 \%$ bila dibandingkan dengan konsentrasi $25 \%, 12,5 \%$ dan $6,25 \%$ memiliki perbedaan yang signifikan, sehingga pada konsentrasi $100 \%$ memiliki keefektifan yang lebih baik dari konsentrasi yang lainnya.

Pada kelompok ekstrak kencur dengan konsentrasi $50 \%$ memiliki perbedaan signifikan dibandingkan dengan konsentrasi 25\%, 12,5\%, dan 6,25\% sehingga pada konsentrasi trsebut memiliki keefektifan yang lebih baik. Pada kelompok ekstrak kencur berkonsentrasi 25\% memiliki perbedaan signifikan dengan konsentrasi $12,5 \%$ dan 6,25\%. Kelompok ekstrak kencur konsentrasi $12,5 \%$ memiliki perbedaan signifikan dengan konsentrasi ekstrak kencur 6,25\%. Data tersebut dikatakan bermakna terdapat perbedaan apabila $\mathrm{p}<0,05$.

Pemberian ekstrak kencur konsentrasi $100 \%$ memiliki daerah zona hambat yang paling besar dibandingkan ekstrak kencur konsentrasi lainnya yang lebih kecil, ini dikarenakan kandungan 
Pengaruh Pemberian Ekstrak Kencur (Kaempferia galanga L.) terhadap Peningkatan Zona... Linda Putri Utami, Peter Gunawan Tandean, Liliawanti

senyawa kimia dari ekstrak kencur seperti senyawa tanin, flavonoid dan minyak atsiri lebih besar atau banyak pada konsentrasi $100 \%$ dibandingkan konsentrasi lainnya yang lebih kecil. Pada pembuatan larutan uji konsentrasi yang lebih kecil, maka diambil $1 \mathrm{ml}$ ekstrak kencur dari konsentrasi yang lebih besar ditambahkan dengan aquades. Maka kandungan kimia dari ekstrak kencur pada konsentrasi 50\%, 25\%, $12,5 \%$, dan $6,25 \%$ tidak sebesar/sebanyak pada konsentrasi 100\%. Begitupun pada konsentrasi $50 \%$ dibandingkan dengan konsentrasi yang lebih kecil, 25\% dibandingkan dengan yang lebih kecil, dan $12,5 \%$ dibandingkan dengan 6,25\%. Data penelitian statistik yang didapatkan, dapat disimpulkan HO ditolak karena terdapat perbedaan dari 7 kelompok perlakuan (minimal sepasang). Dengan terbentuknya zona hambat pada pertumbuhan bakteri Staphylococcus aureus menggunakan media agar berarti ekstrak kencur (Kaempferia galanga L.) memiliki daya antibakteri dalam hal menghambat pertumbuhan Staphylococcus aureus, sehingga disimpulkan $\mathrm{H} 1$ diterima.

\section{PEMBAHASAN}

Dari penelitian ini diketahui bakteri Staphylococcus aureus berhasil dihambat oleh ekstrak Kencur (Kaempferia galanga L.). penelitian ini membuktikan bahwa ekstrak Kencur bersifat Bakteriostatik yang ditunjukkan dengan adanya hambatan yang terbentuk pada media agar Mueller Hinton. Belum diketahui apakah bakteri Staphylococcus aureus yang berhasil dihambat tersebut pada akhirnya mati atau hanya terhambat pertumbuhannya saja. Penelitian dilakukan hanya untuk mengetahui daya hambat dari ekstrak kencur terhadap pertumbuhan bakteri Staphylococcus aureus saja. Dari hasil penelitian yang menunjukkan adanya daya hambat yang diberikan ekstrak kencur terhadap pertumbuhan bakteri Staphylococcus aureus, jika ekstrak ini akan dipatenkan, diharapkan ekstrak kencur ini dapat dijadikan terapi suportif dari terapi utamanya. Karena melihat dari angka zona hambat dari ekstrak kencur ini yang masih lebih kecil dibandingkan kontrol positifnya. Selanjutnya penggunaan Amoxicilin untuk pengobatan infeksi oleh karena Staphylococcus aureus masih diperlukan dan belum bisa digantikan oleh ekstrak kencur.

Terbentuknya zona hambatan pada bakteri yang diujikan disebabkan oleh adanya kandungan antibakteri pada kencur (Kaempferia galanga L.). Daya penghambatan pertumbuhan bakteri disebabkan oleh komponen aktif yang terkandung di dalamnya. Rimpang kencur mengandung alkaloid dan minyak atsiri 
berupa borneol, kamfer dan sineol. Di dalam ekstrak etanol, rimpang kencur mengandung fraksi minyak atsiri yang berwarna cokelat kehitaman. Perbedaan diameter zona hambatan pada bakteri uji disebabkan oleh faktor mekanisme kerja antibiotik. Antibiotik memiliki cara kerja sebagai bakterisidal yaitu membunuh bakteri secara langsung atau bakteriostatik yaitu menghambat pertumbuhan bakteri. Pada kondisi bakteriostatis, mekanisme pertahanan tubuh inang seperti fagositosis dan produksi antibodi biasanya akan merusak mikroorganisme. bahan antimikrobial dapat bersifat bakteriostatik pada konsentrasi rendah namun bersifat bakterisidal pada konsentrasi tinggi. Ada beberapa kerja antibiotik terhadap bakteri sebagai targetnya yaitu menghambat sintesis dinding sel, menghambat sintesis protein, merusak membran plasma, menghambat sintesa asam nukleat, dan menghambat sintesa metabolit esensial (Haerazi et al, 2014)

Rimpang kencur yang pernah
dilakukan yang hasilnya positif
mengandung flavonoid. Senyawa flavonoid merupakan senyawa pereduksi yang baik, menghambat banyak reaksi oksidasi, baik secara enzim maupun non enzim. Flavonoid merupakan golongan terbesar senyawa fenol. Mekanisme kerja flavonoid berfungsi sebagai antibakteri dengan cara membentuk senyawa kompleks terhadap protein extraseluler yang mengganggu keutuhan membran sel bakteri, mengganggu fungsi sel mikroorganisme dan menghambat siklus sel mikroba. Mekanisme kerja dengan cara mendenaturasi protein sel bakteri dan merusak membran sel tanpa dapat diperbaiki lagi

Pada penelitian efektivitas senyawa bioaktif ekstrak kencur (Kaempferia galanga $L$ ) menggunakan pelarut aquades dengan pelarut metanol yang dilakukan memberikan kesimpulan ekstrak metanol kencur menunjukkan adanya aktivitas antibakteri dan diduga senyawa yang bersifat sebagai antibakteri pada ekstrak metanol kencur adalah flavonoid, saponin dan minyak atsiri (Fajeriyati, 2017)

\section{KESIMPULAN}

Dari hasil penelitian yang dilakukan mengenai Pengaruh Ekstrak Kencur (Kaempferia galanga L.) sebagai antibiotik karena dapat menghambat pertumbuhan Staphylococcus aureus dengan metode dilusi dapat disimpulkan bahwa didapatkan perbedaan bermakna pada hasil penelitian aktivitas antibiotik pada berbagai konsentrasi ekstrak kencur dalam menghambat pertumbuhan Staphylococcus aureus. Dengan nilai $\mathrm{p}=0,001$ atau $\mathrm{p}<0,05$ dan Semakin besar konsentrasi ekstrak 
Pengaruh Pemberian Ekstrak Kencur (Kaempferia galanga L.) terhadap Peningkatan Zona...

Linda Putri Utami, Peter Gunawan Tandean, Liliawanti

kencur yang diberikan, semakin besar pula diameter daerah hambat pertumbuhan bakteri Staphylococcus aureus

\section{SARAN}

Berdasarkan hasil yang didapatkan maka dapat disarankan untuk dilakukan Penelitian lanjutan pengaruh pemberian ekstrak kencur (Kaempferia galanga L.) terhadap pertumbuhan bakteri Staphylococcus aureus dengan dosis minimal dan Penelitian lanjutan untuk mengetahui efek samping daripada pemberian ekstrak kencur (Kaempferia galanga L.) jika diberikan dalam jangka waktu panjang dan Perlu dilakukan penelitian dengan pengekstrakan langsung senyawa yang terkandung di dalam kencur (Kaempferia galanga L.) misalnya pengekstrakan langsung senyawa tanin dan saponin, sehingga dapat diuji masingmasing komponen aktifnya terhadap bakteri Staphylococcus aureus.

\section{DAFTAR PUSTAKA}

Elisa N, 2010. Pengaruh Pemberian Madu terhadap Bakteri staphylococcus aureus dan Escherichia coli. Skripsi. Universitas Islam Negeri, Jakarta.

Fajeriyati N dan Andika A, 2017. Uji $\begin{array}{lll}\text { Aktivitas } & \text { Antibakteri } & \text { Ekstrak } \\ \text { Etanol } & \text { Rimpang } & \text { Kencur }\end{array}$
(Kaempferia galanga L.) pada Bakteri Bacillus subtilis dan Escherichia coli. Journal of Currenr Pharmaceutical Science. 1(1): 3641.

Haerazi A, Jekti DSD, and Andayani Y, 2014. Uji Ktivitas Antibakteri Ekstrak Kencur (Kaempferia galanga L.) terhadap Pertumbuhan Bakteri Staphylococcus Aureus dan Streptococcus Viridans. Jurnal Ilmiah Biologi "Bios Cie Ntist". 2(1): 1-11.

Hasanah, 2011. Analisis Kandungan Minyak Atsiri dan Uji Aktivitas Antiinflamasi Ekstrak Rimpang Kencur (Kaempferia galanga L.). Jurnal Matematika \& Sains. 16(3): 147-152.

Inayatullah S, 2012. Efek Ekstrak Daun Sirih Hijau (Piper Betle L.) terhadap Pertumbuhan Bakteri Staphylococcus aureus. Skripsi. Program Studi Pendidikan Dokter, Universitas Islam Negeri, Jakarta.

Kumar A, 2014, Chemical Composition of Essential Oil Isolated from the Rhizomes of Kaempferia galanga L. International Journal of Pharma and Bio Sciences. 5(1): 225-231.

Muhafidzah, 2010. Aktivitas Antioksidan Fraksi Rimpang Kencur (Kaempferia rhizoma) Dengan 
ISSN 1978-2071 (Print); ISSN 2580-5967 (Online) Jurnal IImiah Kedokteran Wijaya Kusuma 9(2) : 145-155, September 2020

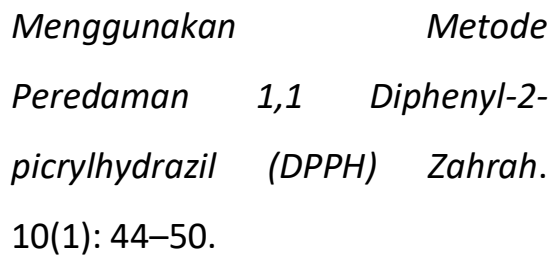

Sari IK, 2017. Uji Efektifitas Antibiofilm Katekin Gambir (uncaria gambir) terhadap Bakteri Staphylococcus aureus Penghasil Biofilm. Skripsi. Fakultas Kedokteran Univesitas Andalas, Padang.

Prabawati TD, Pujimulyani, 2018. Pengaruh Penambahan Ekstrak Kencur (Kaempferia galanga) terhadap Warna, Aktivitas Antiolskidan, dan Tingkat Kesukaan Minuman Instan Kunir Putih (Curcuma mangga val). Seminar Nasional Inovasi Produk Pangan Lokal untuk Mendukung Ketahanan Pangan
Universitas Mercu Buana Yogyakarta.

Primawati SN, and Jannah H, 2019. Pengaruh Metode Ekstraksi Kencur (Kaempferia galanga L.) terhadap Pertumbuhan Staphylococcus aureus. Bioscientist : Jurnal Ilmiah Biologi. 7(2): 177.

MuhAnshar J, Darmawati S, and Dewi SS,, 2017. Ekstrak Daun Bayam Duri (Amaratus Spinosus) terhadap Daya Hambat Pertumbuhan Bakteri Staphylococcus aureus dan Staphylococcus epidermidis. Skripsi. Fakultas IImu Keperawatan dan Kesehatan Universitas Muhhamadiyah Semarang, Semarang. 